\title{
A Solution to the Dilemma of Writing in a Foreign Language: Adaptive Mentorship
}

\author{
Roya Khoii \\ Islamic Azad University, North Tehran Branch
}

\begin{abstract}
This study examined the effect of Adaptive Mentorship on the development of intermediate L2 learners' writing ability. At the outset of the study, the participants filled in two self-confidence and writing attitude questionnaires and placed themselves in the right cells on the D- (protégé's developmental level) and A- (mentor's adaptive required to response) grids of the AM model. They were also required to judge themselves in the form of short reports in terms of self-confidence, writing attitude, and writing competence so that the researcher could classify them more accurately into different groups regarding the above constructs. Finally, a test of writing was administered to the participants to measure their writing ability prior to the treatment. At the end of the 4 month treatment period, which was intended to provide both psychological support and instruction on writing in line with each student's needs following a more individualized approach, the two questionnaires and the $D$ - and A-grids were filled by the participants again. They were also given a writing posttest on the same topic as the pretest. A comparison of the initial and final results revealed that the student writers had made statistically significant improvements in terms of self-confidence, their attitude to writing in a foreign language, and competence in L2 writing.
\end{abstract}

\section{Introduction}

Undoubtedly, writing is the most difficult skill for L2 learners to master. According to Richards and Renandya [1], the difficulty lies not only in generating and organizing ideas, but also in translating these ideas into readable text. They argue that the skills involved in writing are highly complex, and L2 writers have to pay attention to higher level skills of planning and organizing as well as lower level skills of spelling, punctuation, word choice, and so on. The difficulty becomes even more pronounced if student writers are at a low level of language proficiency.

The complex nature of writing has led some researchers to focus on second language writers, specifically second language writer variables. These variables have been divided into five basic categories: second language variables, first language variables, transfer, psychological and sociological variables, and demographic variables [2]. Given the variety inherent in each of these categories, we can see how differently each individual writer might approach a writing task, and how the differences among different students might affect their process of learning to write and producing written texts. Dörnyei and Skehan [3] are right in concluding that individual differences in second language learning have generated the most consistent predictors of second language learning success.

In the field of second and foreign language learning and teaching, learning to write fluently and correctly seems to be of prime importance as a gatekeeping activity; judgments on the performance of an individual may have consequences for the writer, such as exclusion from or successful entry into a specific discourse community. Moreover, it is an important skill in supporting other learning experiences, as a means of recording, assimilating and reformulating knowledge, and of developing and working through the writer's own idea. It may be a means of personal discovery, of creativity and of self-expression.

Given the importance of writing in the field of L2 learning and teaching, the complex nature of this skill, the diversity that characterizes FL writing in terms of writing processes, textual outputs and pedagogical approaches [4], the interplay of social, linguistic and cognitive variables that appear to shape the development of writing ability over time in FL contexts, and the multilingual nature of FL writing, a lot of research has been conducted in order to explore the effect of various techniques on helping L2 learners become better writers. However, it seems that all of these studies focus on the effect of these techniques on the overall performance of the class rather than on how each individual benefits from them in the specific context in which they are learning to write.

Advocating a more individualized approach to teaching writing, the present study was conducted to examine the effect of adaptive mentorship on the development of writing in L2.

\section{Writing in English}

According to Cumming [5], over the past few decades two major, interrelated changes have 
occurred in education internationally: the global spread of English and the increasing prominence and value of written communications. Along with the increasing prominence of English there has been a corresponding expansion in expectations for and about writing in foreign language education. Since the 1980's the increasing research on second language writing has greatly expanded professional knowledge about writing abilities and the multiple components and processes involved in writing. Cumming [5] argues that foreign language writing may represent one set of skills, distinct from reading, listening or speaking as they are commonly considered in curricula and assessments. However, the dimensions of this 'skill' entail numerous micro and macro components and processes that complement and interact with one another at multiple levels of texts, language systems, individual writers, and educational and social contexts. He believes that understanding these elements and their relations points toward what might need to be learned to acquire writing abilities in L2.

At a microlevel are the linguistic elements, text forms, attitudes and thinking processes that a person must acquire and learn to control to write in a foreign language. At a macrolevel are educational and professional policies, the resources and standards applied to implement these policies, norms for writing genres of established discourse communities, and international trends such as the increasing spread and local diversification of lingua franca languages like English [5].

In the field of second and foreign language learning and teaching, learning to write fluently and correctly seems to be of prime importance, and there are several reasons why more research and work need to be done in this area:

1. Many students have specific needs that require them to work on this skill: academic study, examination preparation, and business English are areas where the writing skill is very important.

2. Students need to take notes in lessons, therefore; this skill is worth focusing on.

3. Writing involves a different kind of mental process. There is more time to think, to reflect, to prepare, to rehearse, to make mistakes, and to find alternatives.

4. Writing is one way of providing variety in classroom procedures, and it also makes possible individualized work in large classes.

5. Writing tends to increase retention and makes available the source for later reference.

6. Writing provides a student with physical evidence of his achievement.
However, learning to write is difficult especially for those who write in a second or foreign language; they must write accurately within a limited time. If the English teacher tries to enable students to produce fluent, accurate and appropriate written English, there are a number of aspects which need to be considered (mechanics of writing, accuracy, fluency, etc). That is why during the last 25 years there has been a surge in the studies conducted on the techniques and strategies that might help L2 learners improve their writing ability.

\section{Approaches to writing}

Traditionally, writing teachers are mostly concerned with the final "product" of writing. This approach is totally teacher-centered and product or output-focused. The weaknesses of the product approach are that process skills are given a relatively small role, and that the knowledge and skills that learners bring to the classroom are either ignored or undervalued.

A product-oriented approach to the development of writing favors classroom activities in which the learner is engaged in imitating, copying and transforming models of correct language. This usually occurs at the level of the sentence [6]. While useful in its own place, the product approach does not marry happily with more contemporary views of language and learning concentrating more on language at the level of discourse. In addition, as Nunan [6] observes, instead of looking at completed texts, teachers of writing have become much more interested in the processes writers go through in composing them. Competent writers do not produce final texts at their first attempt. Writing is in fact a long and often painful process in which the final product emerges through successive drafts.

Process approaches are based on the notion that writing is an iterative process. Stages of the writing process can happen in various orders at different points. This writing process is not a rigid, step-bystep activity; it usually involves many twists and turns, moving back and forth. In process approaches, the teacher primarily facilitates the learners' writing, and providing input or stimulus is considered to be less important. Here, the role of a teacher is more as an education facilitator than as a didactic instructor.

The idea behind process writing is not to dissociate writing entirely from the written product and to merely lead students through the various stages of the writing process but "to construct process-oriented writing instruction that will affect performance [7]. To have an effective performanceoriented teaching program would mean that we need to systematically teach students problem-solving skills connected with the writing process [8].

Moreover, according to Zamel [9], the writing class should take into account the learners' purposes 
for writing which transcend that of producing texts for teacher evaluation. Writing skills can develop rapidly when students' concerns and interests are acknowledged, when they are given numerous opportunities to write, and when they are encouraged to become participants in a community of writers. Finally, she suggests that teachers should themselves become action researchers in their own classrooms, apply insights from what they have learned in the most 'profound' way.

Despite insights into the complexities of the composing process revealed by process-oriented studies, most writing classes are still based on mechanistic, product-oriented activities which research has largely discredited [9]. At least, it is still the case in academic situations in the country where this study was conducted. Teachers of writing usually overrate the role of grammatical accuracy and complexity at the expense of fluency of writing. Moreover, in spite of the studies conducted on the great role of psychological/affective factors on the development of the writing skill [10], teachers mainly focus on the formal aspects of their students' written works not only when they are teaching but also when they are providing feedback to them without paying attention to how their approach might affect the students' self-confidence, attitude to writing in L2, and the motivation to write among many other affective reactions.

\section{Feedback to writing}

Providing feedback to students, whether in the form of written commentary, error correction, teacher-student conferencing, or peer discussion has come to be recognized as one of the ESL writing teacher's most important tasks, offering the kind of individualized attention that is otherwise rarely possible under normal classroom conditions [11].

Leki [12] reports that surveys of students' feedback preferences indicate that ESL students greatly value teacher written feedback and consistently rate it more highly than alternative forms, such as peer feedback and oral feedback in writing conferences. He suggests that L2 teachers may be fulfilling several different and possibly conflicting roles as they respond to student writing. When giving feedback, teachers have to choose the appropriate language and style to accomplish a range of informational, pedagogic, and interpersonal goals. Studies of L2 students' reactions to teacher feedback show that learners remember and value encouraging remarks but expect to receive constructive criticism rather than simple platitudes (Ferris, 1995; Hyland, F., 1998, in [11]). However, many teachers are conscious of the potentially damaging effect of critical comments, and this can translate into a reluctance to correct errors directly. Hyland and Hyland [13] suggest that teachers often seek to mitigate the full force of their criticisms and suggestions, taking the sting out of them with hedges, question forms, and personal attribution. Nevertheless, this kind of implicit approach might also lead to the real danger that students may fail to grasp the point and thus misinterpret the response.

Studies on teacher commentary on student writing have highlighted a number of specific issues and implications for L2 writing instructors [14]. Those which are relevant to the present paper include the following:

1. Teachers should provide feedback on all aspects of student texts, including content, rhetorical structure, grammar, and mechanics.

2. Teacher feedback should be clear and concrete to assist students with revision. At the same time, teachers need to be careful not to appropriate student texts.

3. Teacher feedback must take individual and contextual variables into account.

4. ESL writers attend to teacher feedback and attempt to utilize it in their revisions.

The needs, desires and abilities of individual student writers with regard to feedback are often overlooked by researchers and theorists. Teachers, in their efforts to be consistent, may forget that "one size does not fit all" and that different students with different cognitive and affective characteristics may require different types of feedback and guidance in terms of writing.

After all, learning is not something that is set in stone. It is all based on the individual that is learning. The approach and teaching style of the teacher is also an important element in the learning process [15]. In recent years teaching has changed gears and is more centered towards student needs and differences in learning. Teachers are encouraged to differentiate their instruction in order to accommodate all students and their individual needs. Some learn through lectures, some through group work, and some through visual and tactile aids; some need more encouragement in order to boost their motivation and persevere in the process of learning, and some are more motivated and autonomous; some need the teacher's confirmation to gain more self-confidence, and some already have a very high level of selfesteem; some begin the process of learning with fear, apprehension, and hatred, while some others move forward with love and a positive attitude towards the components of learning. Everything is based on the individual these days.

Given the findings of recent studies on Adaptive Mentorship, it appears that this model can be responsive to the needs of individual students in the area of L2 writing. 


\section{Adaptive mentorship}

Mentorship refers to a personal developmental relationship in which a more experienced or more knowledgeable person helps a less experienced or less knowledgeable person. The receiver of mentorship was traditionally referred to as a protégé or apprentice but with the institutionalization of mentoring the more neutral word "mentee" was invented and is widely used today.

There are several definitions of mentoring in the literature. Foremost, mentoring involves communication and is relationship based. In an organizational setting, mentoring can take many forms. One definition of the many that has been proposed is, "Mentoring is a process for the informal transmission of knowledge, social capital, and the psychosocial support perceived by the recipient as relevant to work, career, or professional development; mentoring entails informal communication, usually face-to-face and during a sustained period of time, between a person who is perceived to have greater relevant knowledge, wisdom, or experience (the mentor) and a person who is perceived to have less (the protégé)" [16].

Adaptive Mentorship (AM), formerly called Contextual Supervision, is a promising model that has proven effective in enhancing the mentorship/supervisory process [17]. This model has been derived from a range of contingency and situational leadership approaches [18].

Adaptive Mentorship is a model that focuses on mentors adjusting their mentorship behavior in response to the task-specific development level of protégés they are assisting in the learning/employment situation as represented in Figure 1.

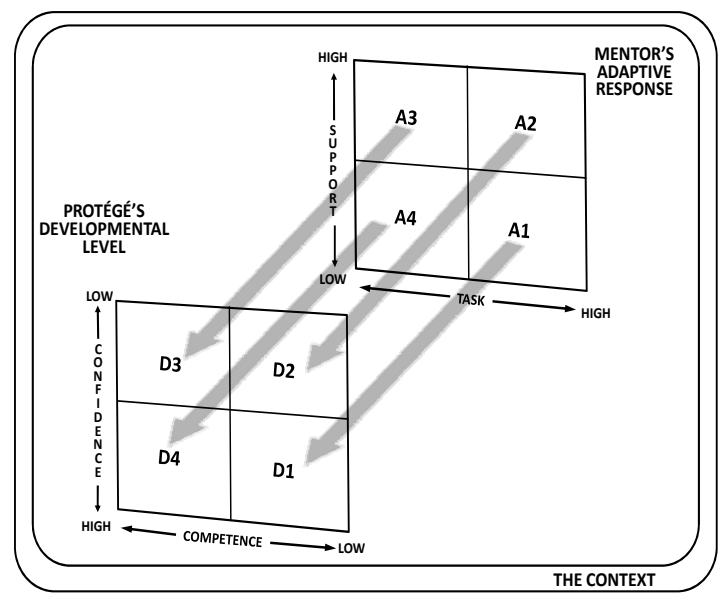

Figure 1. Adaptive mentorship

(The mentor matches his/her adaptive response to coincide with the skill-specific developmental level of his/her protégé. [17]
According to Ralph and Walker [17], the outer border of the diagram represents the context of the mentorship relationship including psychological, social, organizational, and cultural factors within the practicum/work (here, instructional) setting. They emphasize that many of these influences cannot be changed by the mentor or the protégé; however, the key factor over which the participants do have direct control is their own behavior. They add that mentors/instructors can change their mentorship response concerning the two dimensions shown in the A-grid; their adaptive "task" response (the degree of direction given regarding the technical, mechanical, or procedural aspect of the protégé's performance), and their adaptive "support" response (the degree of expression regarding the "human" or psycho/social/emotional aspect of the protégé's learning).

For the protégés, the key element over which they have most control is their competency-specific developmental level in performing particular skillsets [17]. This developmental-level consists of two dimensions: their developmental "competence" level (their ability to perform the task) and their developmental "confidence" level (their degree of self-assurance, composure, and feelings of security and/or safety in performing the skill-set). Ralph and Walker [17] explain that the core of the AM model is represented by the larger arrows linking the D-grid with the A-grid, which portray the mentor's matching of one of four basic adaptive "A" responses with a similarly numbered " $D$ " developmental-level exhibited by the protégé in his/her performance of the particular competency.

Ralph and Walker [19] argue for the transferability of AM because it may be adapted by mentors in any field to assist protégés in developing professional proficiency in their respective contexts.

\section{Methodology}

The present study examined the effect of the application of AM Model to teaching writing as a foreign language. Given the circumstances and the variables under investigation, the teacher functioned as the mentor and the students as the protégés in this study.

\subsection{Participants}

This research was carried out in an intact essay writing class consisting of 24 junior university students studying English Translation at Islamic Azad University, North Tehran Branch. However, the data was collected from 23 of them because one of the participants dropped the course towards the end of the semester. 


\subsection{Instruments and Materials}

The book used for teaching writing in the class was College Writing Skills, John Langan (2004). The following instruments were also used to collect the data on the variables of this study:

a. A modified version of Clément and Baker's English self-confidence questionnaire [20] used both at the outset and end of the treatment

b. The D- and A-grids of the AM Model used both at the outset and end of the treatment

c. A writing attitude questionnaire adapted from Rose [21] used both at the outset and end of the treatment

d. An essay writing pre-test on the topic "The Uses of Computers in Modern Life”

e. The participants' self-evaluation in terms of writing ability, self-confidence, and writing attitude in the form of short reports

f. 16 essays written by students on various topics in various genres

g. Some model essays extracted from the participants' textbook

h. An essay writing post-test on the same topic as the pre-test

\subsection{Applying adaptive mentorship}

According to Ralph and Walker [17], the application of AM consists of three phases: determine development level; 2) synchronize mentor response; and 3) continually observe and adapt mentor response. The researcher tried to follow the same procedure in conducting this study.

1. Determine development level. At the outset of the study, a modified version of Clément and Baker's English self-confidence questionnaire [20] and a writing attitude questionnaire adapted from Rose [21] were given to the participants in order to measure their level of self-confidence and writing attitude prior to the treatment. Then they were asked to place themselves and their previous writing instructors (in the Advanced Writing Course, which is a pre-requisite to the Essay Writing Course) in the right cells on the D- and A-grids, respectively. The related data were carefully collected, entered into Excel sheets, and stored for further analysis. They were also asked to have a self-evaluation of their writing competence and levels of self-confidence and writing attitude, which helped the teacher to have a more accurate recognition of the participants regarding the above constructs. This, in turn, would enable her to provide the right kind of affective and cognitive feedback to the student writers.

Based on the data obtained from the above instruments, the mentor/teacher identified students at varying levels of self-confidence, attitude to writing, and competency in writing. Moreover, she learned about the affective and cognitive feedbacks that the students perceived to have received from their prior writing instructors. This helped her to divide them into different groups in terms of affective and competence dimensions.

2. Synchronize your response. The treatment started with the explanation of the whole writing process, formal rules of writing, different parts of an academic essay, and the significance of developing good writing abilities in one's academic and professional career. Then the students were provided with a sample model essay to observe the rules in practice. In order to measure the participants' writing competence, they were given a writing pre-test on the topic "The Uses of Computers in Modern Life". Their essays were scored holistically by the teacher and one of her colleagues who has been a writing teacher for 12 years. The inter-rater reliability computed through the Pearson Product Moment formula was equal to .92, which was quite satisfactory. The length of each essay was also measured by using the word count option in the Word program.

Each session the students were assigned to write an essay on a given topic related to their needs, interests, and background knowledge. There was some brainstorming on the topic to help them to generate more ideas on the topic and to share them with their classmates. There were always some students who participated more in this process and some who preferred to keep silent most of the time. The mentor tried to recognize them and encourage them to speak out by asking them very simple questions or simply requiring them to write their ideas in the form of outlines and share them with the class. Their participation was greatly encouraged and appreciated by the teacher. Those students at lower levels of self-confidence and with negative attitudes to writing could also receive more assistance from the teacher out of the class at specific times.

Altogether the participants wrote 16 essays in different genres in the course of 4 months. They were required to write their essays at home using the Microsoft Word program. In order to provide the necessary cognitive feedback at the level of the task, the teacher corrected all the essays by marking every single error and providing the correct form and scored them using a holistic approach. She also wrote some notes at the bottom of the paper for every single student. These notes were more encouraging and supportive in the case of low selfconfidence and low attitude students. Some of the good student writers also had a negative attitude to writing and believed that, in spite of receiving enough help at the competence level, they had never received enough affective feedback from their writing teachers so as to continue writing in future. 
They were also recognized and provided with the necessary psychological support.

There were also some students suffering from computerphobia. They were given individualized instruction in terms of word processing, which proved to be highly enjoyable to them. Since the students wrote their essays by computers, they received continued assistance from the word processor in terms of spelling, capitalization, punctuation, grammar, and formatting of their essays, which was of great help to the mentor because of the individualized instruction it provides.

The protégés/students met their mentor once a week in the class but they were free to voluntarily visit her at specific times and receive guidance in terms of writing. They could also mail their problems to the teacher.

3. Continually observe and adapt mentor response. The responses of the students to the Agrid functioned as a useful criterion to the teacher to adapt her mentorship style to the students' developmental levels. She monitored the students' progress closely in terms of competence and selfconfidence by comparing their scores on each essay with their previous performance, their later patterns of participation in class discussions with their earlier ones, and having individual dialogs with them. This helped her to synchronize her adaptive response to match, in inverse degrees, to the students' changing development level. As a student advanced from D1 to D2 to D3 to D4, the teacher would reciprocate by responding correspondingly with $\mathrm{A} 1, \mathrm{~A} 2, \mathrm{~A} 3$, and A4 [17].

At the end of the 4 month treatment, the students were required to fill in the self-confidence and attitude questionnaires and the D- and A- grids again in order to check for any potential changes. Moreover, they were given an essay writing post-test on the same topic as the pre-test to see if there had been any progress in the students' writing competence as a result of the teacher's adaptive behavior. The posttest papers were also scored by two raters. The Pearson Product Formula was used again in order to compute the inter-rater reliability between the two raters. This time it amounted to .91, which was desirable.

\section{Data analysis}

In order to determine if the treatment had been effective, the data were submitted to several statistical analyses. Initially, the descriptive statistics for all the instruments were computed and the mean lengths of the writing pretest and posttest were computed (Table 1).
Table 1. Descriptive statistics for all the instruments

\begin{tabular}{|l|c|c|c|c|c|}
\hline Instrument & $\mathbf{N}$ & Mean & SD & $\begin{array}{c}\text { Min } \\
\text { score }\end{array}$ & $\begin{array}{c}\text { Max } \\
\text { score }\end{array}$ \\
\hline Attitude 1 & 23 & 64.87 & 14.98 & 34 & 101 \\
\hline Attitude 2 & 23 & 73.87 & 10.42 & 52 & 95 \\
\hline $\begin{array}{l}\text { Self- } \\
\text { confidence1 }\end{array}$ & 23 & 37.29 & 7.48 & 19 & 54 \\
\hline $\begin{array}{l}\text { Self- } \\
\text { confidence2 }\end{array}$ & 23 & 42.75 & 8.25 & 30 & 58 \\
\hline Pre-test & 22 & 11.77 & 2.94 & 8 & 17 \\
\hline Post-test & 22 & 15.64 & 1.94 & 12 & 19 \\
\hline $\begin{array}{l}\text { Length 1 } \\
\text { (pre-test) }\end{array}$ & 22 & 344.42 & 79.14 & 187 & 582 \\
\hline $\begin{array}{l}\text { Length 2 } \\
\text { (posttest) }\end{array}$ & 23 & 411.08 & 110.0 & 272 & 737 \\
\hline
\end{tabular}

Then a series of paired-samples t-tests were run in order to check the significance of the differences between the means of the first and second administrations of the different instruments used in this study (Table 2).

Table 2. T-test results for comparison of means

\begin{tabular}{|l|c|c|c|}
\hline Instrument & t-observed & df & Sig (2-tailed) \\
\hline Attitude Qs & 5.055 & 22 & .000 \\
\hline $\begin{array}{l}\text { Self-confidence } \\
\text { Qs }\end{array}$ & 4.654 & 22 & .000 \\
\hline Pretest-posttest & 9.138 & 22 & .000 \\
\hline $\begin{array}{l}\text { Length of pretest } \\
\text { and posttest }\end{array}$ & 3.916 & 22 & .001 \\
\hline
\end{tabular}

As shown in Table 2, all the differences were significant at the 0.05 level. The students had obtained higher scores on the second administrations of the attitude and self-confidence questionnaires comparing to the first ones. The differences are clearly shown in Figures 2 and 3, respectively.

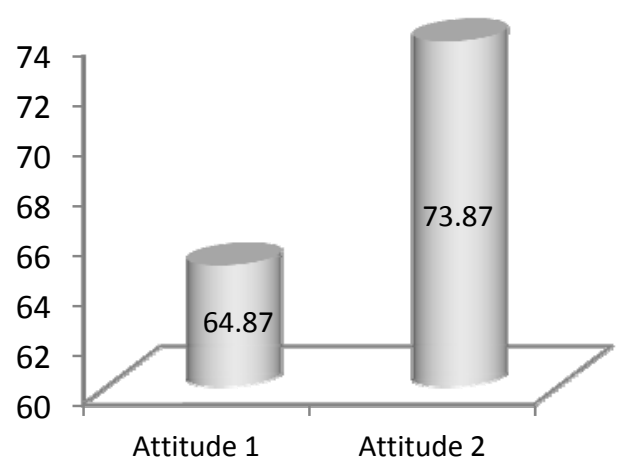

Figure 2. Means of the Two Administrations of the Attitude Questionnaire 


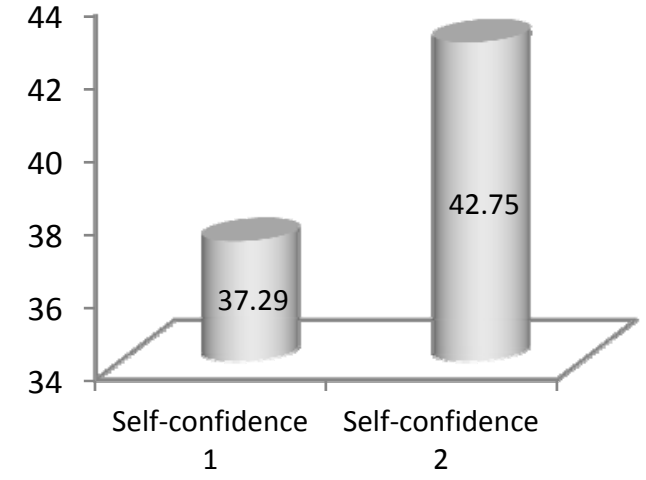

Figure 3. Means of the two administrations of the self-confidence questionnaire

The students also obtained higher scores on their writing posttest as compared to their pretest. Figure 4 illustrates the difference between the means of the students' scores on the writing pretest and posttest.

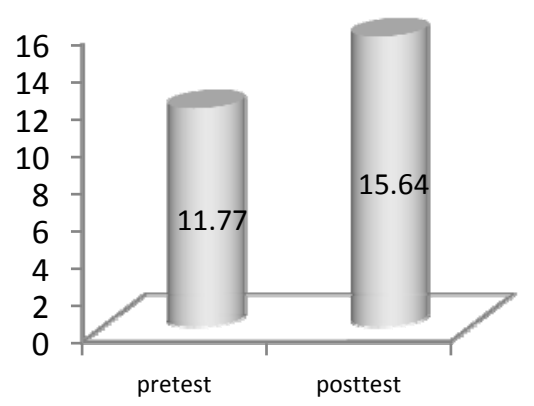

\section{Figure 4. Means of the Writing Pretest and Posttest}

Another interesting finding here pertained to the lengths of the students' writing pretest and posttest. As illustrated in Figure 5, the mean length of the students' scores on the pretest was 344.42, but it increased to 411.08 on the posttest. As mentioned before, the related t-test result indicated that the difference was statistically significant at the 0.05 level.

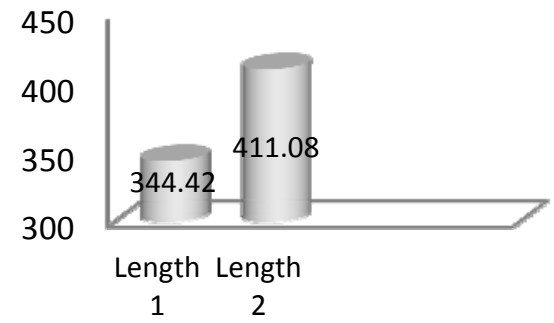

Figure 5. Lengths of the Writing Pretest and Posttest
A comparison of the each individual student's performances on the posttest and pretest also revealed that they were in fact weaker students who had contributed to the rise in the overall means on all the measures used in the study.

In the next stage, the patterns of the responses of the participants to the $\mathrm{D}$ - and A-grids were also compared with each other. According to Ralph [22], D1 typifies an eager novice or enthusiastic beginner; D2 characterizes a fearful neophyte or a disillusioned amateur; D3 describes a reluctant contributor or an insecure leader; and D4 exemplifies a peak performer or a calm expert.

Table 3. Responses to the D-grid on the first and second administrations

\begin{tabular}{|c|c|c|}
\hline $\begin{array}{c}\text { Cells in the D- } \\
\text { grid }\end{array}$ & $\begin{array}{c}\text { First } \\
\text { Administration }\end{array}$ & $\begin{array}{c}\text { Second } \\
\text { Administration }\end{array}$ \\
\hline D1 & 2 & 8 \\
\hline D2 & 12 & 3 \\
\hline D3 & 7 & 4 \\
\hline D4 & 2 & 8 \\
\hline
\end{tabular}

As indicated in Table 3, on the first administration of the D-grid, there were 12 disillusioned amateurs (D2), 7 reluctant contributors (D3), 2 eager novices (D1), and 2 calm experts (D4). After using their responses to the A-grid as a criterion for providing mentorship, their responses to the $\mathrm{D}$ grid were also studied at the end of the treatment. This time there were 3 disillusioned amateurs (D2), 4 reluctant contributors (D3), 8 eager novices (D1), and 8 calm experts (D4).

A comparison of the responses to the A-grid on the two administrations also revealed some promising results. As shown in Table 4, comparing to only 3 cases of match between the cells on the Dand A-grids at the outset of the study, there were 13 cases of match at the end of the experiment. This revealed that the mentor had been quite successful in adapting her mentorship behavior to the developmental level of the mentees, which had resulted in their improving their writing ability, selfconfidence and attitude to writing.

Table 4. Responses to the A-grid on the first and second administrations

\begin{tabular}{|c|c|}
\hline First administration & Second administration \\
\hline 3 & 13 \\
\hline
\end{tabular}




\section{Discussion}

The purpose of the researcher in this study was to demonstrate that following a more individualized approach to writing which is based on human relationships can help foreign language learners overcome some of their problems when writing in L2. Based on the obtained results, it was concluded that replacing teaching with a more individualistic style of supervision based on the Adaptive Mentorship model can be a promising experience. It was also found that a deeper understanding of interpersonal considerations can influence foreign language writers both affectively and cognitively.

According to Hyland and Hyland [11], "Students vary considerably in what they want from their teachers in the form of feedback." They also maintain that students have their own concerns and agendas, and it is important that teachers seek to discover these and try to address them in their feedback. Writing teachers need to tailor their comments to specific students and their needs and personalities, as well as to the teaching context. The application of Adaptive Mentorship assisted the researcher to recognize the specific needs of her students to a great extent and to provide each of them with the appropriate type of response. The analysis of the collected data led her to believe that the participants had managed to raise their level of selfconfidence, develop a more positive attitude to writing, and improve their writing ability.

A very interesting point here was the low level of attrition in the class. The researcher's experience shows that usually one third of the students leave writing classes during the first month of instruction and, at most, only half of them take the final exam. In this study, the class started with 24 students and finished with 23 students.

Following a "one size fits all" approach in instructional settings usually leads to pre-judging and marginalizing some of the students and creates antagonism, agonism and, in best cases, neutrality on the part of less self-confident and less proficient students. In this way, good writers become better writers, but weaker ones feel frustrated and develop a very negative attitude towards all the components of the writing process and writing course. The application of the AM Model revealed that using a style that is more responsive to each individual student's cognitive and affective needs will lead to better performance in terms of writing and improves the writer students' self-image and attitude to writing.

\section{Future work}

The results of this study can be of interest to L2 teachers who are looking for newer techniques to help their students solve their problems with learning to write in a foreign language. However, the application of this model certainly requires some training on the part of teachers. They should transform their conception of their own role as teachers into mentors and supervisors. In other words, instead of trying to prescribe the same rules for good writing and providing the same kind of feedback to all kinds of students, they should accept the philosophy of "one size does not fit all” and try to individualize their method of teaching to some extent in order to meet their students' various needs. L2 teachers are also recommended to use this Model in teaching other foreign language skills and areas such as reading, speaking, listening, vocabulary, phonology, and grammar.

\section{Acknowledgements}

This research was supported by a grant from Islamic Azad University, North Tehran Branch. The researcher would like to express her deepest appreciation to Professor Edwin Ralph, who greatly inspired her for conducting this research by the excellent workshop he conducted in Canada International Conference on Education (CICE 2010).

\section{References}

[1] Richards, J. C. and W. A. Renandya, Methodology in Language Teaching: An Anthology of Current Practice, Cambridge University Press, Cambridge, 2002.

[2] Leki, I., A. Cumming, and T. Silva, A Synthesis of Research on Second Language Writing in English, Routledge, New York, 2008.

[3] Dörnyei, Z. and P. Skehan, "Individual Differences in Second Language Learning" in The Handbook of Second Language Acquisition, C. J. Doughty and M. H. Long (Eds.), Blackwell, Oxford, 2005.

[4] Manchón, R. M., "Broadening the Perspective of L2 Writing Scholarship: The Contribution of Research on Foreign Language Writing" in Writing in Foreign Language Contexts: Learning, Teaching, and Research, R. M. Manchón (Ed.), Multilingual Matters, Bristol, 2009.

[5] Cumming, A., "The Contribution of Studies of Foreign Language Writing to Research, Theories and Policies" in Writing in Foreign Language Contexts: Learning, Teaching, and Research, R. M. Manchón (Ed.), Multilingual Matters, Bristol, 2009.

[6] Nunan, D., Language Teaching Methodology: A Textbook for Teachers, Prentice Hall, Maylands (UK), 1991.

[7] Freedman, S., A. Dyson, L. Flower, and W. Chafe, Research in Writing: Past, Present, and Future, University of California Press: Center for the Study of Writing (Technical Report No. 1), Berkeley, 1987. 
[8] Seow, A., "The Writing Process and Process Writing” in J. C. Richards and W. A. Renandya, Methodology in Language Teaching: An Anthology of Current Practice, Cambridge University Press, Cambridge, 2002.

[9] Zamel, V., "Recent Research on Writing Pedagogy", TESOL Quarterly, 1987, 21 (4): 697-715.

[10] Dörnyei, Z., “Attitudes, Orientation, and Motivations in Language Learning: Advances in Theory, Research, and Applications. Language Learning, 2003, 53 (sup.) 3-32.

[11] Hyland, K. and Hyland, F., Feedback in Second Language Writing: Contexts and Issues, Cambridge University Press, New York, 2006.

[12] Leki, I., "The Preferences of ESL Students for Error Correction in College Level Writing Classes”, Foreign language Annals, 24 (3), 1991, 203-218.

[13] Hyland, F. and Hyland, K., Sugaring the Pill: Praise and Criticism in Written Feedback, Journal of Second Language Writing, 10 (3), 2001, 185-212.

[14] Ferris, D., "Responding to Writing" in Exploring the Dynamics of Second Language Writing, B. Kroll (Ed.), Cambridge University Press, New York, 2006.

[15] Mark, L., "Importance of Individualized Teaching”, Journal of Classroom Teaching and Learning, March, 2009.

[16] Bozeman, B. and M. K. Feeney, Toward a Useful Theory of Mentoring: A Conceptual Analysis and Critique, "Administration and Society", 39 (6), 2007, 719 - 739.

[17] Ralph, E. G. and K. Walker, "Enhancing Mentors' Effectiveness: The Promise of the Adaptive Mentorship Model”, McGill Journal of Education, Vol. 45, No. 2, Spring 2010.

[18] Fiedler, F. and J. Garcia, New Approaches to Leadership, Cognitive Resources and Organizational Performance, John Wiley and Sons, New York.

[19] Ralph, E., Walker, K., and Wimmer, R, "The Clinical/Practicum Experience in Professional Preparation: Preliminary Findings", McGill Journal of Education, 2008, 43(2), 157-172. Available from: http://mje.mcgill.ca/article/view/682/2242.

[20] Clément, R., and Baker, S. C., Measuring Social Aspects of L2 Acquisition and Use: Scale Characteristics and Administration, Technical Report, University of Ottawa, Ottawa, Canada, 2001.

[21] Rose, M., Writer's Block: The Cognitive Dimension, Carbondale, IL: Southern Illinois University Press. 1984.

[22] Ralph, E., "Contextual Supervision: Matching Supervisory Styles with Learners' Needs”, Canadian Administrator, 1996, 35 (3), 1-11. 